\title{
Globalisation: Context and Controversies
}

\section{Tony Makin}

$\mathrm{G}$ lobalisation is the dynamic process driving the integration of national markets for goods, services and assets with markets elsewhere in the world. As the very term suggests, globalisation has been far reaching geographically, affecting lifestyles, production, consumption and work practices in all hemispheres of the world. It means that economies have become far more interdependent as a result of greatly increased flows of exports, imports and foreign investment. With increased international economic interdependence, production, spending and finance are less constrained by political borders.

The arguments for free international trade first espoused by the classical British economists, Adam Smith, David Ricardo and John Stuart Mill, still provide the strongest intellectual foundation for advocating globalisation. Meanwhile, there has been a long history of outright hostility toward high levels of foreign trade and investment, stretching back to Vladimir Lenin's wrong-headed view that foreign investment was inherently exploitative of host countries and represented the last stage of global capitalism.

This paper first gauges the extent of globalisation and its main causes technological advance and market liberalisation policies implemented worldwide. It then evaluates key issues in the ongoing debate about globalisation, before placing the phenomenon in historical context. Next, it addresses concerns about the contribution of financial globalisation to economic crises in emerging economies. Finally, it contends that globalisation is likely to continue to intensify well into the future.

\section{Extent and Causes}

The value of the sum of exports and imports, a measure of economic openness, has more than doubled over recent decades in Australia and other advanced economies. In many developing economies, the pace of globalisation as reflected in growth in the volume of international trade in goods and services has been even faster (see Figure 1), accompanied by strong growth in foreign investment and cross-border financial flows.

Economists would argue that this rapid internationalisation helps explain why many developing economies grew so quickly from the 1960's. Economies in South East Asia, such as Malaysia, Singapore and Thailand for example, have significantly higher proportions of trade to GDP ratios than many OECD economies. 


\title{
Figure 1: Volume of World Trade in Advanced and Developing Economies
}

\author{
Annual Percent Change, Ten Year Average
}

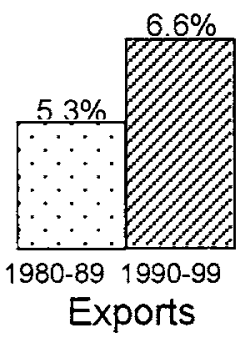

Advanced
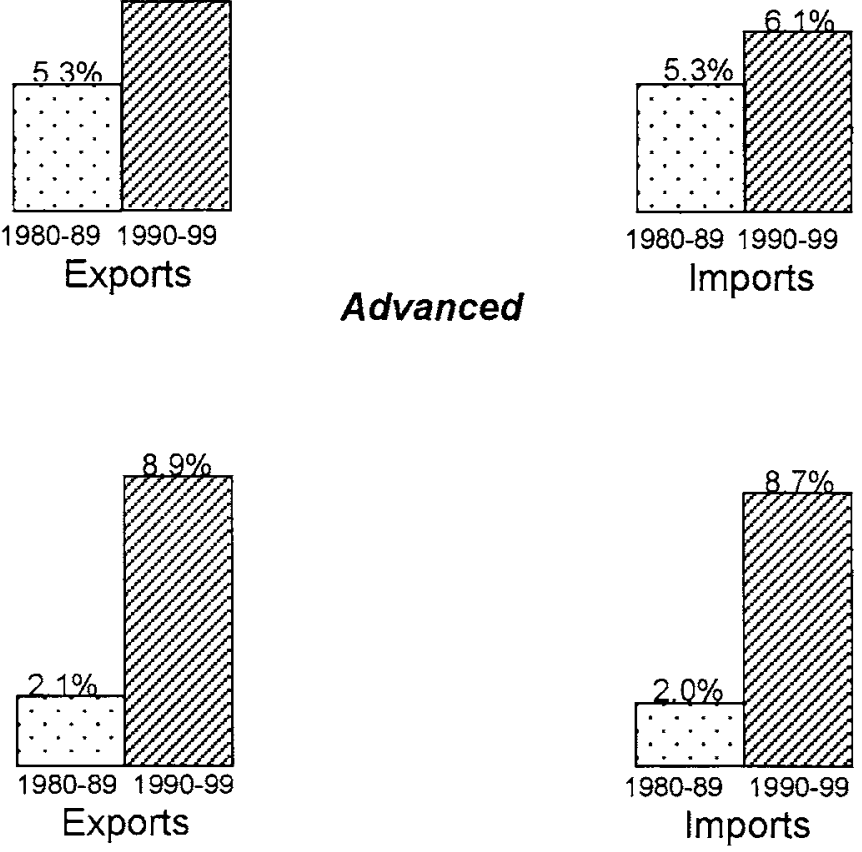

Developing

Source: Based on data from International Monetary Fund, World Economic Outlook, May 1998.

The two fundamental causes of globalisation have been leaps in technology and the liberalisation of markets for goods, services and finance. Technological advance has revolutionised communication via facsimile, email and the Intemet, shrinking the natural barriers of time and distance. Real computer processing costs have fallen an average of $30 \%$ per annum over recent decades (The Economist, 1997) and the cost of communicating has also been dramatically reduced. For instance, the real cost of phoning New York from anywhere in Australia is a tiny fraction of what it was decades ago. 
In addition, numerous supranational institutions established after the Second World War when political internationalism reached its zenith have fostered globalisation. Under the auspices of the World Trade Organisation (WTO), and its predecessor body, the General Agreement on Tariffs and Trade (GATT), many governments around the world have actively promoted freer international trade in goods and services over recent decades, though not without serious disagreements along the way. Large regional trading groupings, such as ASEAN, NAFTA, the European Union, Mercosur and APEC have also been founded to encourage increased cross border trade flows by eliminating import quotas, tariffs and export restraints.

At the same time, the deregulation of international capital markets has also substantially improved access to the pool of global saving for advanced and emerging economies. Many economies have experienced much larger external account imbalances in the form of current account deficits associated with these capital inflows, with these external imbalances providing a measure of the extent to which foreign funds enable additional economic activity in host countries.

What also characterises this era of globalisation is the role and prevalence of foreign direct investment and the multinational company, many of which have turnovers greater than the national incomes of individual nations. The momentum of growth in foreign direct investment, cross-border mergers and acquisitions and international production since the early 1980's is evident from the annual average growth rates included in the table below

Table 1: Global Foreign Direct Investment

\begin{tabular}{lcc}
\hline & \multicolumn{2}{c}{ Annual growth (per cent) } \\
& $1986-90$ & $1991-99$ \\
\hline FDI Inflows & 23.6 & 20.1 \\
FDI Outflows & 27.1 & 15.1 \\
Cross border mergers and acquisitions & 21.0 & 30.2 \\
Sales of foreign affiliates & 16.3 & 13.4 \\
Gross product of foreign affiliates & 16.6 & 6.2 \\
Total assets of foreign affiliates & 18.3 & 24.4 \\
\hline
\end{tabular}

Source: UNCTAD (1998:2).

\section{Arguments For and Against}

Economists familiar with the principles of international trade theory naturally endorse globalisation on the grounds that increased international integration of 
markets expands exchange opportunities. By enabling greater international division of labour and more effective allocation of resources, including saving and finance, globalisation allows producers to reap rewards from specialisation and consumers to enjoy a wider range of product choice at the cheapest prices.

However, globalisation continues to provoke dissent from non-economists who seem as much opposed to market processes and capitalism as a system of production and exchange, as to globalisation per se (see Burtless et al., 1998). These opponents generally do not question the economic growth enhancing power of globalisation, but instead are pre-occupied with equity considerations, claiming that the very poor in globalising economies are further impoverished through the process.

This is ultimately an empirical issue, with the evidence suggesting to the contrary that incomes of the poor in a wide range of countries at various stages of development rise equivalently with incomes overall (Dollar and Kraay, 2000). While concerns are raised about a widening differential between the earnings of skilled and unskilled labour in many economies as they undergo internationalisation, it should be recognised that the fundamental source of this divergence is technological advance, not globalisation.

In economic policy debate in countries around the world, protectionist sentiment and concern about the impact of foreign investment also remain central to the views of economic nationalists whose policy platforms reflect strong antipathy to globalisation. There are losers from the process of liberalising trade and investment in advanced economies, the worst affected being the owners and employees of previously highly protected firms in industries that find it difficult to compete with more efficient foreign producers. Yet, the fact remains that economies that have adopted free trade principles and internationally oriented development strategies have prospered more than those economies that have favoured protectionist, inward looking strategies.

While there is widespread agreement amongst economists and policymakers about the longer-term benefits of free trade in goods and services, there is relatively less recognition of the benefits of free investment. Many commentators neglect that as a result of foreign investment, economies have been able to invest more domestically, and hence grow faster than otherwise, while generating higher yields for international investors. On this basis, the process of international capital market integration and the associated rise in international capital mobility have been, in theory, welcome developments. ${ }^{1}$

Furthermore, in the context of heightened financial globalisation, international investors judge domestic fiscal stabilisation measures that boost public spending harshly whenever such spending is deemed unproductive. Accordingly, this has alienated those Keynesians who favour frequent and active use of public spending to smooth out business cycle fluctuations. In a globalised economy, if international investors disapprove of fiscal activism and the

I Makin (2000) elaborates on the macroeconomics of international capital market integration. 
associated higher budget deficits, foreign investment, direct and financial, could diminish, resulting in higher long-term domestic interest rates, less real capital accumulation and consequently a lower rate of economic growth. ${ }^{2}$

Foreign investment in the form of subsidiary operations of large multinational companies enables technology to be transferred from advanced economies to emerging and less developed economies. For this reason, governments of all political persuasions around the world, are today in constant competition to attract foreign investment of this type, sometimes using specific tax concessions and subsidies for this purpose.

Meanwhile, conservationists tend to oppose globalisation because greater economic activity harms the environment. There is no denying that real environmental problems do arise as a consequence of accelerated economic growth, as indeed they did in advanced economies during the Industrial Revolution, and this remains the most challenging issue in the debate. Nonetheless, opponents of globalisation should appreciate that democratically elected governments in many emerging economies perceive environmental problems as a by-product of a development process they choose to prolong in order to raise average income levels.

\section{How New?}

In light of the extensive discussion of the causes and effects of globalisation over recent years, it would seem that many would have us believe that the world economy is going through a phase like no other before. The process of globalisation is not, however, an economic phenomenon that first began in, or is exclusive to, the late twentieth century. The world economy has previously experienced an era of globalisation during the so-called la belle epoque, that was similar in many respects to the present one.

This first era of globalisation coincided with the gold standard system that governed all international economic transactions and ended with the Great War. In the gold standard era (1870 to 1914), many economies were increasingly internationalised by large trade and investment flows due to the emergence of additional markets in the New World. During this period, there were also substantial movements of people, emigrating mainly from the economies of Britain and Western Europe to colonies and former colonies in North America, South America, Africa and Australasia. In common with the current era of globalisation, the earlier era was spurred by major breakthroughs in technology that greatly improved transport and communications, such as the telegraph, railways and steamships. ${ }^{3}$

At the beginning of this century, international capital flows between some nations, such as Britain and its former colonies Australia and Canada, as reflected

2 Latham (1998) provides a useful Australian political perspective on globalisation that contrasts with the economic nationalist views of Buchanan (1998) for the United States.

3 For related discussions, see IMF (1997) and Williamson (1996). 
in current account imbalances, actually exceeded levels of today measured in terms of national production. The share of exports in world output for instance, reached a peak in 1913 that was not surpassed again until 1970. Moreover, in the first globalisation era, migration rates and international labour mobility were also proportionately higher than they are today. Yet geographically, globalisation was then actually less global in its reach. Now more parts of the world, including in Asia, Latin America and Eastern Europe are affected, with trade in services also much greater than ever before.

After the Great War, international goods markets generally disintegrated through the 1920's and this reversal of the rise of globalisation continued through the 1930's and 1940's as a result of escalating tariffs on internationally traded goods, unstable exchange rates, the Great Depression and the Second World War. After the war, the International Monetary Fund (IMF) was established to oversee the Bretton Woods system that survived until the early 1970's. The General Agreement on Tariffs and Trade (GATT) was also founded at this time for the purpose of scaling back tariffs and other protective measures that had restricted growth in international trade. Irwin (1995) provides a discussion of the achievements of the GATT.

Under the Bretton Woods system which aimed to restore the exchange rate stability of the gold standard era, international capital flows were heavily controlled in order to assist central banks maintain exchange rates at predetermined levels. A major reason why nations agreed to fix exchange rates was that this was seen as a way of minimising exchange rate uncertainty that was thought to deter international trade flows.

The Bretton Woods system eventually collapsed because of excessively lax monetary policy in the United States, due in part to the need to pay for the Vietnam War. ${ }^{4}$ The fixed exchange rates under the Bretton Woods system were also difficult to sustain in a global financial environment where international capital flows were continually growing. A comprehensive history of international monetary arrangements is provided by Eichengreen (1996). An irony was that this strong growth in international capital flows was in part attributable to a reemergence of increased volumes of exports and imports of goods and services that often had to be financed.

So, in a sense, the Bretton Woods system that had been designed to facilitate globalisation as it applied to increasing trade in goods and services, itself became a victim of globalisation as it applied to increased flows of international investment. Yet, despite the earlier views of the architects of the Bretton Woods system, the worldwide fluctuations in exchange rates that have occurred since the 1970 's under the present 'non-system' of international monetary arrangements have not in fact stymied the growth of international trade. On the contrary, trade volumes have continued to rise thanks to the development of sophisticated instruments of exchange rate risk management.

4 See Mundell (2000) for related discussion. 


\section{Financial Globalisation and Economic Crises}

The heightened international interdependence of financial markets has altered the way domestic fiscal and monetary policies once operated under closed economy conditions and has exposed economies to the risk of international capital flight. Yet, many macroeconomists still subscribe to the view that fiscal fine-tuning can readily alter economy-wide spending and hence aggregate employment opportunities. Closed economy thinking in this vein neglects the telling influence of international financial markets over exchange rate and interest rate behaviour. These developments have created doubts about the globalisation process, particularly as it relates to international capital flows, previously a concern of the architects of the Bretton Woods system as suggested above.

The adverse consequences of this exposure to international investment swings became starkly evident for many East Asian economies during their 199798 financial crisis. Although financial crises had earlier occurred in Latin America in the 1980's, the sharp reversal in 1997-98 of international capital inflows to previously fast-growing Asian economies easily represents the most significant international adjustment so far in this relatively new era of globally integrated capital markets.

This switch of foreign investment in conjunction with the flight of domestic investors' funds abroad caused very large depreciations against the US dollar of the Indonesian rupiah, Thai baht, Malaysian ringgit, Philippines peso and South Korean won. This sudden reversal of short-term international capital flows to the East Asian economies has therefore prompted calls to limit the scale of such flows with many proposing that tighter restrictions be put in place by emerging economies to limit the quantum of foreign funds that are borrowed and lent across their borders.

What this interpretation of events tends to ignore however is that without earlier capital inflow from abroad, Asian economies would be on a considerably lower plateau of economic development. Thanks in large part to globalisation, average income increased four-fold in Malaysia, Indonesia and Thailand over the three decades from 1965 to 1995 and a remarkable seven-fold in South Korea. These growth rates were significantly above historical averages recorded in times pre-dating the present era of globalisation and remain unparalleled by any other group of economies elsewhere in the world this century.

Exchange rate management policies gave international investors a misplaced sense of exchange rate stability because many East Asian central banks had for some years successfully limited exchange rate variation, although there had been substantial once-only changes in previous decades. Unsatisfactory prudential supervision of financial institutions in these economies was also a major contributing factor to financial crises.

Domestic banks had often been established with insufficient capitalisation and incompletely reformed financial systems were prone to rapidly expanding bank credit and high levels of unhedged foreign debt. Similarly, provision of economic information on the nature of government-business relations and the size of external debt exposure and non-performing loans was limited, evidence of a general lack of 
transparency in financial dealings. Further discussion of the Asian crisis is available in Goldstein (1998), Eichengreen (1999) and Makin (1999).

International capital flows in effect act like a vehicle carrying an economy from one stage of development to another. To get to the destination of higher national income, funds need to flow through the financial system that plays a similar role to a highway. This vehicle-highway-destination analogy is a useful device for thinking about how best to minimise occasional crises, or accidents, that occur on the way to higher economic growth.

One crisis minimisation option is to tax the use of vehicles. In this vein, a so called 'Tobin tax' originally proposed by James Tobin (1978) would apply to currency conversions related to short-term international capital flows. This tax would be difficult to implement worldwide however, and avoidance problems would surface. Alternatively, the best way to minimise accidents while simultaneously allowing maximum travel is to upgrade the highway to make travel safer, as well as providing more advisory signs along the way.

In effect, this will only be achieved through major redesign of the practices governing the way many financial institutions operate in emerging economies. This could include more private sector involvement in preventing and resolving crises ('bail ins'), greater financial market disclosure, tighter capital adequacy and supervision rules. In the wake of the Asian financial crisis, further financial globalisation is not likely to proceed as quickly again in many emerging countries until these financial reforms are firmly in place and recognised as such by the international investors, including major multinational banks.

\section{The Future of Globalisation}

These days very few economists dispute the theoretical proposition that free trade in goods and services improves economic growth, national income and hence overall economic welfare. As long as governments worldwide continue to appreciate the economic arguments in its favour, the process of globalisation should intensify into the future, notwithstanding some stalling along the way due to periodic financial crises.

The main difference between the contemporary international economic and political environment and la belle époque is that there now exists a wellestablished supranational institutional framework fostering international economic exchanges. In contrast, in the first globalisation era, all economic institutions were strictly nationally based and no independent authorities existed to oversee the economic conduct of participants in international exchange.

The current framework is comprised of numerous international institutions pursuing pro-globalisation objectives, such as the Organisation for Economic Cooperation and Development, the World Trade Organisation, the International Monetary Fund and the World Bank. In this regard, although the raison d'etre, objectives and policies of these taxpayer-funded organisations are by and large economically sound, at the same time it is difficult to disagree with suggestions 
that their activities should be more transparent and their non-elected officials more accountable.

To conclude, considerable potential remains for increased integration of the markets for commodities, manufactures, services and financial assets. The proportion of trade to national income remains relatively small for many advanced and developing economies, both relative to the past and relative to the most open economies in the world. Additionally, most of the domestic investment that occurs in many economies is still financed by locally sourced saving, which implies that much greater scope exists for increasing the scale of international saving and investment flows.

\section{References}

Buchanan, P. (1998), The Great Betrayal, Little Brown, New York.

Burtless, G., R. Lawrence, R. Litan and R. Shapiro (eds) (1998), Globaphobia: Confronting Fears About Open Trade, Brookings Institution, Washington DC.

Dollar, D. and A. Kraay (2000), Growth Is Good for the Poor, Development Research Group, World Bank, Washington DC.

Eichengreen, B. (1996), Globalising Capital: History of the International Monetary System, Princeton University Press, Princeton.

Eichengreen, B. (1999), Toward a New International Financial Architecture: A Practical Post-Asia Agenda, Institute for International Economics, Washigton DC.

Goldstein, M. (1998), The Asian Financial Crisis, Institute for International Economics, Washington DC.

International Monetary Fund (1997), 'Globalisation in Historical Perspective', in World Economic Outlook, May, IMF, Washington DC.

Irwin, D. (1995), 'The GATT in Historical Perspective', American Economic Review 85(May):323-28.

Latham, M. (1998), Civilising Global Capital: New Thinking for Australian Labor, Allen and Unwin, Sydney.

Makin, A. (2000), Global Finance and the Macroeconomy, Macmillan and St Martins Press, London and New York.

Makin, A. (1999), 'The Great East Asian Capital Flow Reversal: Reasons, Responses and Ramifications' The World Economy 22(3):407-419.

Mundell, R. (2000), 'A Re-consideration of the Twentieth Century' American Economic Review, 90(3):327-340.

The Economist (1997), 'One World?', 18 October:99. 
Tobin, J. (1978), 'A Proposal for International Monetary Reform', Eastern Economic Journal 4:153-159.

UNCTAD (1998), World Investment Report: Trends and Determinants, United Nations, New York.

Williamson, J. (1996), 'Globalisation, Convergence and History', Journal of Economic History 56(June):277-306.

The author acknowledges the useful comments of the editors and an anonymous referee. 